\title{
Will Open Government make Canada's health agencies more transparent?
}

\author{
Paul C. Hébert MD, Jane Coutts BA BAA, Matthew B. Stanbrook MD PhD, Noni MacDonald MD MSc, \\ Ken Flegel MDCM MSc
}

$\mathrm{O}$ n Mar. 18, 2011, the Harper government announced its "Open Government" strategy. ${ }^{1,2}$ Although it appears to have been borrowed from President Barack Obama's Open Government directive, ${ }^{3}$ the piecemeal and toothless approach adopted in Canada falls short of the openness that has become the default position of all government departments in the United States. ${ }^{4}$ To follow the US example, openness in health information would require directing Health Canada and the Public Health Agency of Canada first to be part of the approach and then to develop and report on how they will concretely achieve more "open government."

The opacity and culture of secrecy of some of Canada's federal health agencies must be addressed. As far back as 2000, Dr. Roberta Bondar, chair of Health Canada's Scientific Advisory Committee, said that the drug approval process had become more efficient, but she harshly criticized the department "for a level of confidentiality that is inconsistent with public expectation and contributes to public cynicism about the integrity of the process." 5

The committee had good reason to complain. The federal approach to overseeing pharmaceuticals and devices demonstrates the lack of transparency at Health Canada. ${ }^{6}$ Neither research evidence nor details of company submissions to launch new medications and devices are publicly available. Health Canada does not announce dates for approval hearings, provide the relevant information or offer the public reasons for its decisions. It defends this approach by saying commercial interests supersede the need for disclosure.

In contrast, the US Food and Drug Administration (FDA) announces topics it is examining, posts timetables for hearings and invites public submissions. When a regulatory decision is reached, the FDA will post the evidence considered, who provided opinions (and their competing interests), the value it placed on different patient outcomes and, ultimately, a detailed rationale for the decision. Such clear and transparent descriptions ensure that the public can readily understand the rationale for complex decisions - such as that behind granting market approval for a new drug that dramatically reduces symptoms of a disease but increases rates of death. A recent example of transparent disclosure on a complex decision is the removal of the indication for use of monoclonal antibody bevacizumab for breast cancer. The FDA produced a podcast to explain its position clearly; Health Canada still remains silent on recent postmarket research involving this drug.

As a result of the FDA's transparency, stakeholders in the US have a better chance of determining whether commercial or economic interests overruled patient safety and health outcomes when a decision about a drug was made. The US system has its faults and detractors, but it is undeniably more open, transparent and accountable than Health Canada's.

The US also has legislation to ensure that all clinical trials used in submissions are publicly registered and the results posted on ClinicalTrials .gov, a database run by the National Institutes of Health. This database and others prevent companies from hiding negative results from the public. Academics have access to the positive and negative data needed to write thorough, systematic reviews of new drugs. Health Canada does not yet require companies to register trials.

The Harper government's recent decision to suspend the implementation of a long-standing plan to refresh and strengthen anti-smoking labels was yet another example of closed-door decisionmaking. ${ }^{7}$ Only after criticism by provincial government representatives and public health advocates gained widespread publicity did the program move forward again with a clear timeline.

If Open Government is to be implemented effectively in the health sector, it must be led from the top. However, despite earlier election promises, the Harper government has proven to be the antithesis of open. Prime Minister Stephen Harper has centralized all communications through his office, where controlling hands muzzle ministers, bury controversial decisions and extensively censor documents released to the public. This is not a culture that will drive a shift to Open Government in Health Canada.
Competing interests: See www.cmaj.ca/misc /cmaj_staff.dtl. None declared for Jane Coutts.

Affiliations: Editor-inChief (Hébert), CMAJ; Ottawa-based writer and editor and President of Coutts Communicates (Coutts); Deputy Editor Scientific (Stanbrook);

Section Editor, Public

Health (MacDonald);

Senior Associate Editor (Flegel), CMAJ

Correspondence to: $C M A J$ editor, pubs@cmaj.ca

CMAJ 2011. DOI:10.1503 /cmaj.110411 
If the Harper government has truly changed its attitude and hopes to open government to Canadians, it should start by instructing Health Canada to make all regulatory submissions more open - by releasing the data it used, or mandating companies do so, by regularly holding open meetings, just as the FDA does, and publicly posting detailed rationales for its decisions. ${ }^{8}$

As testimony before the Standing Committee on Access to Information, Privacy and Ethics indicates, the US Open Government results in a "paradigm shift" that has begun to yield health benefits through the innovative use of combined government datasets with new technologies., ${ }^{9,10}$ However, innovation, collaboration and greater accountability will not materialize without establishing meaningful deliverables as well as monitoring and reporting on success. Without targets, Canadians might end up with more websites devoid of searchable and relevant information.

This change will not be easy. Senior government officials and experts will argue that they need a safe space to provide fearless advice. Industry, including pharmaceutical, biotechnology and device companies, will protest that such openness threatens their intellectual property and commercial interests. Ministers will be wary of the questions that may be raised.
But secrecy and lack of public involvement undermine accountability and the credibility of public institutions and their decisions. They diminish public trust and feed conspiracy theories. Failure to truly implement Open Government risks being perceived as little more than marketing by the Harper Government.

\section{References}

1. Expansion of Open Government. Ottawa (ON): Treasury Board; 2011. Available: http://open.gc.ca/media/0318a-eng.asp (accessed 2011 Mar. 18)

2. Vogel L. Federal government unveils modest transparency initiative. CMAJ 2011; Mar. 21 [Epub ahead of print].

3. Open Government directive. Washington (DC): The White House; 2009. Available: www.whitehouse.gov/open/documents /open-government-directive (accessed 2011 Mar. 13).

4. Transparency Task Force. FDA transparency initiative: improving transparency to regulated industry. Washington (DC): US Department of Health and Human Services: Food and Drug Administration; 2011. Available: www.fda.gov/downloads /AboutFDA/Transparency/TransparencytoRegulatedIndustry/Phase IIITransparencyReport/UCM239088.pdf (accessed 2011 Feb. 28).

5. Report of the Committee on the drug review process. Ottawa $(\mathrm{ON})$ : Health Canada; 2000.

6. Dhalla I, Laupacis A. Moving from opacity to transparency in pharmaceutical policy. CMAJ 2008;178:428-31.

7. Stanbrook MB, Hébert PC. The federal government's senseless policy change on tobacco warning labels. CMAJ 2010:182: 1939-40.

8. Wright JM. Progressive drug licensing: an opportunity to achieve transparency and accountability? CMAJ 2007;176:1848-9.

9. Vogel L. The secret's in: open data is a foreign concept in Canada. CMAJ 2011; Mar. 14 [Epub ahead of print].

10. Vogel L. Opening the gates on US government data. CMAJ 2011; Mar. 15 [Epub ahead of print].

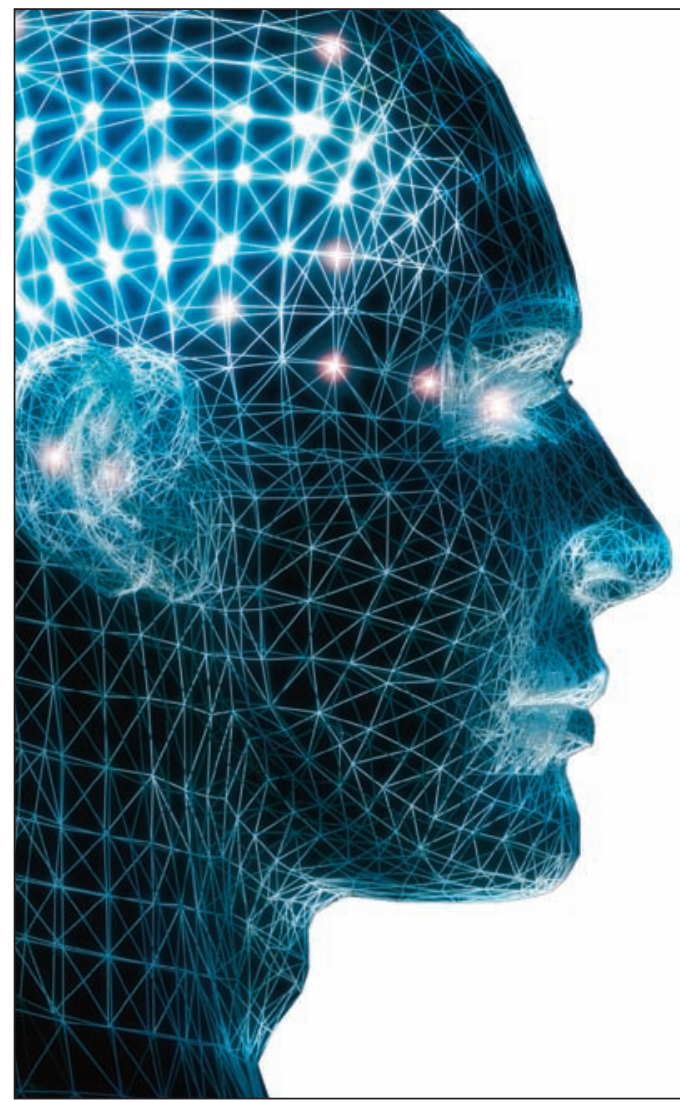

\title{
Be one of the first to know!
}

\author{
And sign up for Weekly Alerts of new content \\ posted on cmaj.ca
}

Don't miss out on online-only news and research articles that you won't see in print.

Go to www.cmaj.ca/cgi/alerts/etoc to sign up!

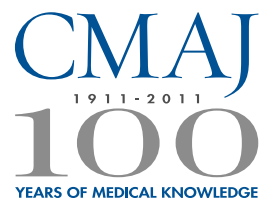

